YEARBOOK of ANTITRUST and REGULATORY STUDIES www.yars.wz.uw.edu.pl
Peer-reviewed scientific periodical, focusing on legal and economic issues of antitrust and regulation. Creative Commons Attribution-No Derivative Works 3.0 Poland License.

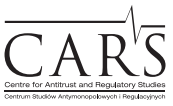

Centre for Antitrust and Regulatory Studies, University of Warsaw, Faculty of Management www.cars.wZ.uw.edu.pl

\title{
Joint and Several Liability of Competition Law Infringers in the Legislation of Central and Eastern European Member States
}

\author{
by
}

\author{
Péter Miskolczi Bodnár and Róbert Szuchy*
}

\section{CONTENTS}

I. Introduction

II. Joint and several liability under the Damages Directive

1. Disciplines in the Damages Directive

2. Liability of immunity recipients

3. Responsibility of small and medium-sized enterprises

4. Underlying reasons

5. Issues

5.1. Norm drafting

5.2. Interpretation of joint and several liability

5.3. Ceilings of the liability of immunity recipients to other co-infringers

5.4. Responsibility of SMEs

III. Joint and several liability of co-infringers in CEE countries

1. Joint and several liability of co-infringers as a general rule in the 11 CEE Member States

2. Exception rules to joint and several liability of co-infringer in CEE countries

* Péter Miskolczi Bodnár - Professor of Law at the Department of Commercial and Financial Law at the Faculty of Law of Károli Gáspár University (Budapest, Hungary), former member of the Competition Council of the Hungarian Competition Authority, miskolczi.bodnar.peter@kre.hu; Robert Szuchy is an Associate Professor in the Department of Commercial and Financial Law at the Faculty of Law of Károli Gáspár University (Budapest, Hungary). Besides his university carrier, he is a member of the Hungarian Bar Association and practice as the Managing Partner of his law firm which provides legal services for energy companies in Hungary and in other countries as well. In 2016 he was elected to be the ViceDean of the Faculty. szuchy.robert@kre.hu. Article received: 21.07.2017; accepted: 18.09.2017. 
3. Assessment of the justification of exceptions to joint and several liability of co-infringers

IV. Position of the immunity recipient in national laws

1. Relationship of the immunity recipient and the injured parties

2. Relationship of the immunity recipient and other co-infringers

2.1. Starting date of the payment obligation of the immunity recipient

2.2. Factors determining the internal share of the responsibility among co-infringers

2.3. Maximum degree of liability of the immunity recipient

V. Exemption of SMEs from joint and several liability in national laws

1. Scope of ratione personae of the special liability rule

2. Whether SMEs are exceptions to joint and several liability?

3. Circumstances underlying the exemption from joint and several liability of SMEs

4. To what kind of harm is the principal responsibility of SMEs limited?

VI. Links of the regulation

1. Liability of a co-infringer reaching a settlement through consensual dispute resolution

2. Liability of parent companies

VII. Proposal

\section{Abstract}

The study reviews the provisions of the Directive by, first, presenting its general rule - joint and several liability - and then its two exceptions, pointing out that albeit they contain similar solutions, these have different reasons in the case of leniency applicants obtained immunity from fines and small and medium-sized enterprises. The study examines whether the 11 CEE Member States prescribe joint and several liability, in principle, to cases where multiple persons cause harm jointly by an infringement of competition law. The study also analyses the position of an immunity recipient in national laws. During the examination, the study separates the position of the immunity recipient and the injured parties, as well as the position of the immunity recipient and other co-infringers, as is the case in the Directive. The study summarizes also national experiences with the implementation of the Damages Directive. It is a fact that the norms of the Directive have been implemented, and there is no deviation to jeopardize either the enforcement of claims for damages or the integrity of the internal market.

Nevertheless, having established two separate exceptions, it would have been duly justified for the Commission to explain them in detail, considering their rules differ from each other. Noticeably, some CEE countries considered the difference unjustified and uniformly provided an opportunity for the co-infringer who compensated the harm of an injured party to submit a reimbursement claim against the immunity recipient and SMEs. Other CEE countries considered that they did not have the authority to do so. 
It would be worth reviewing the implementation of the exceptions to joint and several liabilities after a year, in conjunction with the issue of alternative dispute resolution.

The study makes a proposal for an amendment of the Directive. Doctrinal views related to the SMEs exemption from joint and several liability draw attention to the fact that it is unfortunate if solutions designed in a relatively late stage of the legislative procedure do, in fact, later become a part of that directive.

It would seem practical, for example, to declare that this exception shall be applied also to micro enterprises in relation to the compensation of harms caused by infringements of competition law. The Damages Directive requires, however, the implementation of this exception only with regard to small and medium-sized enterprises.

\section{Résumé}

L'étude examine les dispositions de la Directive en présentant tout d'abord la règle générale - la responsabilité solidaire - puis ses deux exceptions, en soulignant que même si elles contiennent des solutions similaires, elles ont des raisons différentes dans le cas des demandeurs de clémence qui ont reçu une immunité et des petites et moyennes entreprises.

L'étude analyse si les onze États Membres d'Europe centrale et orientale prévoient, en principe, la responsabilité solidaire dans les cas où plusieurs personnes causent un dommage conjointement par une infraction au droit de la concurrence. L'étude analyse également la position d'un bénéficiaire de l'immunité dans les lois nationales. Pendant l'évaluation, l'étude sépare la position du bénéficiaire de l'immunité et des personnes lésées, ainsi que la position du bénéficiaire de l'immunité et des autres contrevenants, comme c'est le cas dans la Directive.

L'étude résume également les expériences nationales avec la mise en œuvre de la Directive Dommages. Il est vrai que les normes de la Directive ont été mises en œuvre et qu'il n'y a pas d'écart qui pourrait mettre en péril les actions en dommages ou l'intégrité du marché intérieur.

Néanmoins, après avoir établi deux exceptions distinctes, il aurait été dûment justifié que la Commission explique ces exceptions en détail, en prenant en compte qu'ils se diffèrent les uns des autres.

Il faut noter que certains pays d'Europe centrale et orientale ont considéré que la différence était injustifiée et ont prévu de manière uniforme que le contrevenant qui compensait le préjudice d'une personne lésée pouvait présenter une demande de remboursement contre le bénéficiaire de l'immunité et les PME. D'autres pays d'Europe centrale et orientale ont estimé qu'ils n'avaient pas le pouvoir de le faire. Il serait intéressant d'examiner la mise en œuvre des exceptions à la responsabilité solidaire après un an, en combinaison avec la question du règlement extrajudiciaire des différends.

L'étude propose une modification de la Directive. Les opinions doctrinales concernant l'exonération de la responsabilité solidaire des PME soulignent qu'il est 
regrettable que des solutions conçues au stade relativement avancé de la procédure législative fassent ultérieurement une partie de cette directive.

Il semblerait pratique, par exemple, de déclarer que cette exception s'appliquera également aux micros entreprises en ce qui concerne la réparation des préjudices causés par des infractions au droit de la concurrence. Cependant, la Directive Dommages n'exige la mise en œuvre de cette exception que pour les petites et moyennes entreprises.

Key words: joint and several liability; maximum degree of liability; micro, small and medium-sized enterprises; full compensation, proportional reimbursement; direct or indirect purchasers and suppliers; ceilings of the liability of immunity recipients.

JEL: K12; K13; K15; K21

\section{Introduction}

A cartel inevitably has multiple members. By contrast, it is usual for only one entity to be in a dominant position, thus multiple perpetrations take place only exceptionally in the case of abuses of a dominant position. Nonetheless, legislation shall pay attention to those infringements of competition law which are committed by multiple persons. In the case of harm caused by such competition law breaches, the legal relationship between infringers and injured parties is of a specific nature. This study examines the liability of infringers towards injured parties (external relationship) on the one hand, and, on the other hand, analyses the rules on the relationship between multiple infringers (internal relationship).

Civil laws traditionally create special rules on harm caused by multiple entities. Infringers are typically jointly and severally liable towards injured person(s). Based on joint and several liability, the injured party may claim even full compensation of its harm from any of the infringers. Alternatively, the injured party may claim compensation from multiple infringers in a proportion considered appropriate. Joint and several liability of the infringers is beneficial to the injured party from several points of view.

First, it facilitates actions against infringers, a fact of importance mainly if the group of infringers includes foreign nationals or undertakings with residences unknown to the injured entity. Second, the fact that the injured party does not have to hunt for each infringer is likely to result in a faster recovery of its harm. Third, joint and several liability considerably reduces the risk that the injured party fails to receive full compensation as a result of the insolvency of any of the infringers. In comparison with shared responsibility, 
joint and several liability places the risk on all infringers that any of them (part of them) becomes insolvent and thus unable to pay its share of the harm caused. Finally, it is also an advantage of joint and several liability that legal disputes on the share of the liability between infringers do not cause a delay in providing compensation since the co-infringers do not have to decide on what share of the harm are individual infringers liable for. Such a separate lawsuit may still be necessary, but it occurs between co-infringers already after the injured party had received its compensation.

In case of infringements of competition law, ${ }^{1}$ Directive 2014/104/EU of the European Parliament and of the Council of 26 November 2014 on certain rules governing actions for damages under national law for infringements of the competition law provisions of the Member States and of the European Union (hereinafter, 'Damages Directive') considers the application of joint and several liability appropriate in principle, while laying down exemptions to that rule.

\section{Joint and several liability under the Damages Directive}

\section{Disciplines in the Damages Directive}

The Directive lays down certain principles - it declares the right to full compensation (Article 3(1)), and places a duty on the Member States to have national legislation that makes possible the actual enforcement of the compensation (Article 3(2)). Moreover, Member States shall also ensure the equivalent assessment of harms caused by an infringement of national and European competition law (Article 4)(Peyer, 2016, p. 91).

In case of harm caused by multiple persons, the Damages Directive expects from the Member States, in principle, the application of joint and several liability of the co-infringers. Joint and several liability of co-infringers means - in external relations - that all injured parties may claim damages for their harms from any of the infringers until the harm has been fully compensated. ${ }^{2}$ The internal relations of co-infringers are governed by the first sentence of Article 11(5) of the Damages Directive. In the relationship between

\footnotetext{
${ }^{1}$ Infringements of competition law: violation of Art. 101 and 102 of TFEU or national competition law - Art. 2(1) of the Directive 2014/104/EU of the European Parliament and of the Council of 26.11.2014 on certain rules governing actions for damages under national law for infringements of the competition law provisions of the Member States and of the European Union, OJ L 349, 05.12.2014.

2 Damages Directive, Art. 11(1).
} 
co-infringers, the Damages Directive mentions only the right to 'recover a contribution from any other infringer'. It leaves the determination of the amount to be claimed to the Member States, because it mentions only 'the amount of which shall be determined in the light of their relative responsibility for the harm caused by the infringement of competition law'. According to our understanding, the infringer that has actually paid a bigger amount of compensation than its own share of the claims of the injured parties under national law may request the difference from other co-infringers, and if they fail to provide their contribution voluntarily, the paying infringer may bring an action against them as well.

The European Commission considers certain exceptions to the general rule of joint and several liability appropriate.

\section{Liability of immunity recipients}

Detection of typically secret cartel agreements, and bringing cartels to an end, is greatly facilitated by rules that promise immunity from fines for that cartel member which provides the relevant competition authority with appropriate evidence on the cartel. Such leniency policies significantly contribute to the detection of cartels. However, the usage to leniency is minimized by the fact that cartel members revealing a cartel are exempted only from fines levied by competition authorities, but not from the payment of compensation. Until the payment of compensation constituted only a danger in theory (very unlikely in practice), immunity from administrative fines created sufficient incentives for leniency to work. However, the Damages Directive envisages that in the future, cartelists face a real risk of having to pay compensation. This will hinder detection based on leniency submissions of current and future cartels but, at the same time, hopefully dissuading many others from entering cartels in the first place. In order for the risk of compensation not to deter cartel members from stopping their cartel behaviours, and to provide evidence on the cartel, the European Commission wants to ensure a more favourable position to those infringers that cooperate with the authorities. This preferential treatment relates to the liability sphere, and affects both the external relations between infringers and injured parties, as well as internal relations among co-infringers.

Pursuant to the Damages Directive, leniency applicants exempted from the fine imposed in competition law proceedings (hereinafter, 'immunity recipients') shall be separated from other infringers in the realm of national law; national legislators shall prescribe less stringent liability rules for immunity recipients. Two groups of injured parties shall be distinguished. The immunity recipient shall pay compensation only for harm suffered by its own direct or 
indirect purchasers and providers. ${ }^{3}$ In other words, immunity recipients are exempted from the burden that other injured parties (other than its own direct or indirect purchasers and providers) may claim damages directly from them. They are liable to other injured parties only if the latter cannot receive full compensation from other co-infringers. ${ }^{4}$

In their internal relations, infringers may, in principle, claim between each other an amount based on their own portion of the responsibility for the harm caused. Immunity recipients are thus placed in a more favourable position, than that granted by the general rule, also in the internal relations with their co-infringers. The amount of the 'contribution' to be paid by an immunity recipient shall not exceed the sum of the harm caused to its own direct or indirect providers and purchasers. If another co-infringer actually compensates the harm, the immunity recipient is also in a favourable position with regard to the paying co-infringer's claim against the immunity recipient, because its reimbursement obligation shall not exceed the total sum of the harm caused to the immunity recipient's own direct or indirect providers and purchasers. ${ }^{5}$

\section{Responsibility of small and medium-sized enterprises}

Similarly to the general rule concerning immunity recipients, small and medium-sized enterprises (hereinafter, SMEs) shall not bear responsibility against all those injured by the cartel. Small and medium-sized enterprises shall only compensate harm suffered by their own direct or indirect purchasers. However, this rule is subject to conditions, and the exceptions specified in the Directive shall also be taken into account. ${ }^{6}$ The Damages Directive does not contain a rule (unlike with respect to the immunity recipient) whereby a SME would be obliged to compensate the harm of injured parties other than its own direct or indirect providers or purchasers, if they fail to get compensation from other co-infringers. The phrase used in the Directive, whereby the aforementioned rule is applied without prejudice to the right to full compensation, may serve as a basis to reason for the existence of vicarious liability. On the other hand, if the requirements provided for in the Directive

3 Pursuant to Art. 2(23) 'direct purchaser' means a natural or legal person who acquired, directly from an infringer, products or services that were the object of an infringement of competition law; 'indirect purchaser' means a natural or legal person who acquired, not directly from an infringer, but from a direct purchaser or a subsequent purchaser, products or services that were the object of an infringement of competition law, or products or services containing them or derived therefrom. The direct or indirect providers are not defined in Art. 2.

${ }^{4}$ Damages Directive, Art. 11(4).

5 Ibidem, Art. 11(5).

6 Ibidem, Art. 11(2)-(3). 
are satisfied (that is, the SME is failing), a SME has hardly the assets to cover a claim submitted by another co-infringer.

\section{Underlying reasons}

Out of the two aforementioned cases, the interest of the injured party is easy to be recognized behind the first. The European Commission protects the best interests of all injured parties by giving preferential treatment to those infringers that facilitate the effectiveness of competition enforcement procedures, thus exempts the infringer from joint and several liability in a certain sphere. Without mitigating joint and several liability of immunity recipients, evidence necessary to determine an infringement of competition law would not become available, thus all injured parties would be in a far worse situation.

The second case mentioned above is specific because the Damages Directive tries here to deviate from its own joint and several liability of co-infringers rule, not favouring the injured party by any means. The European Commission makes at this point an exception only to save SMEs. This solution is contrary to the aim set out in the Damages Directive, namely the protection of injured parties; however, it fully corresponds with European measures favouring SMEs. Having regard to the fact that SMEs are not entitled to favourable treatment if they lead the infringement in question or have committed an infringement of competition law before, this responsibility norm while favourable to SMEs, nevertheless facilitates deterrence from future infringements.

\section{Issues}

\subsection{Norm drafting}

It is unfortunate that the Damages Directive separates the rules concerning the external and the internal relations of co-infringers. The right of injured parties to submit a claim against any of the co-infringers is laid down in Article 11(1). The provision concerning the internal relations of the co-infringers is included in the first sentence of Article 11(5), which was placed among rules concerning immunity recipients.

\subsection{Interpretation of joint and several liability}

On the one hand, Article 11(4) of the Damages Directive refers to the liability of an immunity recipient towards its direct and indirect purchasers and 
providers. On the other hand, it refers to the liability of an immunity recipient towards other injured parties as joint and several. It does so despite the fact that it lays down the responsibility against these two groups of injured parties according to non-identical rules. In our opinion, the liability of an immunity recipient towards injured parties other than its own direct and indirect purchasers and providers is, in fact, a form of vicarious liability. Against such injured parties, immunity recipients are, in principle, exempted from joint and several liability of co-infringers, since compensation shall be paid in this context only if all other co-infringers prove unable to cover the damage caused.

\subsection{Ceilings of the liability of immunity recipients to other co-infringers}

The second sentence of Article 11(5) of the Damages Directive fixes the maximum liability level of immunity recipients - an immunity recipient shall not pay more than this maximum amount to those co-infringers who have actually paid the compensation. According to our standpoint, this provision determines the maximum amount to be paid by an immunity recipient in terms that are too vague.

Surely, a given immunity recipient may not be aware of the identity of all its direct and indirect purchasers and providers, as it may not be familiar with these undertakings. First, an immunity recipient might not know to whom its 'direct purchasers' sell products distributed by that immunity recipient or pass on services provided by that immunity recipient (the first group of 'indirect purchasers'). Second, it is even more difficult to know to whom these 'indirect purchasers' passed on these products and services (the second group of 'indirect purchasers'). Third, a similar difficulty might lie in knowing those natural and legal persons, who produce goods or services derived from the goods and services distributed by that immunity recipient (the third group of 'indirect purchasers'). Fourth, the immunity recipient might not be able to identify those indirect providers that provide components, semi-finished goods and services for direct providers that are in contact with the immunity recipient, as buying cartels affect negatively not only those in direct contact with the cartel members but also indirect providers. Because of the low price paid to direct providers being in contact with the immunity recipient, the direct provider is able to pay only a smaller price to its own providers.

The identity of a significant part of the indirect purchasers and providers becomes known to an immunity recipient only after they file a claim for damages and, in this context, after they provide evidence concerning the contested transactions.

On the other hand, an immunity recipient does not know, for a long time, the amount of the harm suffered by its direct or indirect purchasers and providers. 
If that amount is contested, the degree of the harm caused by the immunity recipient to its own direct or indirect purchasers and providers becomes clear only after the court decision settling the legal dispute becomes final. Until this moment, the immunity recipient may not know the ceiling of its responsibility towards other co-infringers. Immunity recipients find themselves in difficulty when facing a claim for damages, as it is the immunity recipient itself who should prove the maximum rate of their responsibility, but at least for a while, it will not be able to do so.

We shall differentiate among four situations, depending on who makes the claim against an immunity recipient and for what kind of compensation of harms.

(1) If an injured party belonging to the group of 'own direct and indirect purchasers and providers of the immunity recipients' submits a compensation claim for damages from an immunity recipients, the latter may not evade it. After paying such compensation, the immunity recipient may claim a contribution towards the paid compensation from other co-infringers. The issue of the maximum amount of harms does not play a role here. When the immunity recipient compensates the harm of an injured party belonging to its own direct and indirect purchasers and providers, it will not exceed the amount of harm caused to injured parties belonging to its own direct and indirect purchasers and providers, because the damages claimed from him are part of that overall amount.

(2) If a person other than 'own direct and indirect purchasers and providers of the immunity recipient' submits a compensation claim for its harm from the immunity recipient, the position of the latter depends on the behaviour of its other co-infringers. If there is a chance for other co-infringers to compensate the harm, the immunity recipient may reject the payment of such compensation. The issue of the maximum level of liability of an immunity recipient comes into focus here, however, if the injured party proves that its damages claims towards other co-infringers were unsuccessful or that a part of its harm has not been recovered. In this case, if the immunity recipient can prove that it compensated the harm suffered by its direct and indirect purchasers and providers, it may be exempted from the compensation of the harm of an injured person other than its own direct and indirect purchasers and providers. As a matter of digression, it may occur, in principle, that the immunity recipient exceeds the maximum degree of its liability by paying compensating in full the harm suffered by injured parties other than its own direct and indirect purchasers and providers. In this case, compensation should only be paid up to the extent of that cap. 
However, due to the aforementioned evidentiary difficulties, until the last direct or indirect purchaser or provider makes its claim, or, if the amount of harm is disputed, until the amount of compensation to be paid is not set by a final judgment of the court, the immunity recipient may not take advantage of the limitation of the maximum degree of liability the Directive provides for.

(3) If an immunity recipient faces a claim made by a co-infringer, which has already covered the harm suffered by an injured party, for the payment of a contribution towards the already paid damages, one has to examine whose harm was covered by the co-infringer that submits such contribution claim. If the claimant covered the harm of an injured party other than 'own direct and indirect purchasers and providers of the immunity recipient', the immunity recipient may reject the claim for a contribution from the paying co-infringer. In this case, the immunity recipient does not take part in the distribution of the already paid compensation (as a situation where the harm of the injured party has not been covered does not exist). Thus, in this case, it is not necessary to refer to the maximum degree of the liability of the immunity recipient, the latter may reject the claim for a contribution upon the applicable rule of special joint and several liability (in fact, secondary liability).

(4) If a co-infringer compensated the harm of an injured party belonging to 'own direct and indirect purchasers and providers of the immunity recipient', the immunity recipient shall take part in the distribution of the paid compensation. The payment of compensation could not have been refused if such an injured party had made the claim against the immunity recipient directly. The maximum degree of liability has no relevance in this case either, because if the immunity recipient covers its share of the harm of an injured party belonging to its own direct and indirect purchasers and providers, this compensation cannot exceed the overall amount of harm which was caused to all injured parties belonging to this group, because the individual compensation claimed from the immunity recipient is only a part of the overall liability amount.

The European Commission was likely focusing on a situation when the immunity recipient compensates the harm caused to its own direct and indirect purchasers and providers, but refuses claims submitted by other injured parties. After covering the harm caused to its own direct and indirect purchasers and providers, the immunity recipient may invoke the limited nature of its own liability against an injured party who does not belong to that group but has not received compensation from other co-infringers. The defence of the immunity recipient may be successful from the point when it has indeed covered the harm caused to its own direct and indirect purchasers and providers and reached the 
maximum degree of its own liability. This assumption seems logical, but it does not take into account the possibility that it might turn out, in a relatively short period of time, that an injured party not belonging to the aforementioned group does not receive compensation from other co-infringers, and so it will claim compensation from the immunity recipient. The latter may thus become a defendant in an action for damages before it manages to compensate all of the harm caused to its own direct and indirect purchasers and providers (which constitutes the fact that determines the maximum degree of its liability). Therefore, notwithstanding the rule protecting immunity recipients, the latter will more than likely be forced to cover the harm of some injured parties not belonging to their own direct or indirect purchasers and providers, because at the time of the claim, the degree of compensation paid by a given immunity recipient has not yet reached the maximum degree of its own liability or, if its amount cannot be proved. In these cases, it would be advisable to suspend the seizing of the action for damages against such immunity recipient.

\subsection{Responsibility of SMEs}

While the Damages Directive refers to Commission Recommendation 2003/361/EC in connection with SMEs, the definition of SMEs is, in fact, laid down in Commission Regulation (EU) No. 651/2014 of 17 June 2014.

The exemption from joint and several liability is subject to arguments when it comes to SMEs - it seems that joint and several liability is not only applied as a general rule, but its total exclusion is considered justified in Brussels. This exception rule may, in certain cases, hinder injured parties from getting full compensation. Thus the special provision on SMEs jeopardizes the achievement of the fundamental goal of the Damages Directive.

The Damages Directive describes the liability of SMEs as an exception to joint and several liability of co-infringers ('By way of derogation from paragraph 1'). Upon the strict literal interpretation of the rules provided for in the Damages Directive, the liability of SMEs for harm caused to their direct and indirect purchasers may not be considered joint and several liability either. We believe that other co-infringers are jointly and severally liable together with the SMEs for these harms as well. It is likely that the Damages Directive intended to exempt joint and several liability only for those harms which were suffered by injured parties other than 'own direct and indirect purchasers of the SMEs'. 


\section{Joint and several liability of co-infringers in CEE countries}

\section{Joint and several liability of co-infringers as a general rule in the $11 \mathrm{CEE}$ Member States}

The 11 Central and Eastern European Member States (CEE countries) prescribe, in principle, joint and several liability if multiple persons jointly cause harm by their behaviour that infringes competition law (Piszcz, 2017a, p. 302). CEE countries get this result (set out in the Damages Directive as an aim) thanks to two kinds of solutions.

One group of CEE countries did not need to make any harmonization efforts because their respective Civil Codes (or maybe separate Acts on Contract $\mathrm{Law}^{7}$ ) consider joint and several liability as applicable in the case of co-infringements. Their legislation contains also exceptions, or makes it possible for courts to waive joint and several liability under certain circumstances. ${ }^{8}$ Civil Codes do not typically mention harm caused by competition law infringements separately, but joint and several liability (as a general legal consequence) is applicable to harm caused by infringements of competition law also. ${ }^{9}$ This group of CEE countries had the task of determining which of its laws must not be applied in case of co-infringements of competition law. ${ }^{10}$

Concerning the other group of CEE countries, ${ }^{11}$ their new legislations expressively declare that co-infringers which breach competition law are, in principle, held liable jointly and severally. Incidentally, it does not emerge from the national reports why, in general, these Member States deem this step necessary during the implementation of the Directive. For instance, the reports were not clear whether the respective rule of the Civil Code is applicable to infringements of competition law, or whether the Civil Code contains any rules at all on joint and several liability.

Joint and several liability means the same in both groups, namely that the injured party may claim damages from one of the co-infringers. Consistently also, the infringer that compensated the damages of an injured party may claim its proportional reimbursement from other infringers.

7 For example: Estonia, Slovenia.

8 Bulgaria, Czech Republic, Estonia, Lithuania, Hungary, Poland, Slovenia.

9 'As a rule, CEE countries do not need to introduce the principle [of joint and several civil liability of competition law infringers], as the national reports assert - they already have it in their laws with regard to competition law infringements,' (Piszcz, 2017a, p. 302).

10 For example: in Hungary during the amendment of the act on competition it was declared that other than in the Civil Code, the court may not ignore joint and several liability in case of infringements of competition law.

11 Croatia, Latvia, Romania, Slovakia. 


\section{Exception rules to joint and several liability of co-infringers in CEE countries}

What the legislations of CEE countries had in common, before the adoption of the Damages Directive, is that their contract laws had not contained any exception rules, which would have exempted a group of co-infringers from joint and several liability based on their individual characteristics (e.g. financial situation of a co-infringers) or special behaviour of a co-infringer which behaviour should be independent of the action which has led to the harm (e.g. fact-finding activity of the immunity recipients during the competition law procedure). The Damages Directive caused the legislatures of all of the examined countries to adopt new rules on immunity recipients and SMEs. They all implemented these rules; there is only a difference in the date of their implementation.

In Hungary and in Slovakia, immunity recipients were exempted from joint and several liability already according to the White Paper, hence even before the adoption of the Damages Directive (Miskolczi Bodnár, 2017, p. 129 and Blažo, 2017, p. 253). These regulations were later amended in light of the actual Directive. Other countries awaited the adoption of the Damages Directive and introduced relevant national rules (draft rules) with content appropriate to the Directive that is, containing the special exceptions (Piszcz, 2017, p. 19).

\section{Assessment of the justification of exceptions to joint and several liability of co-infringers}

Generally, the rapporteurs do not query the exemption given to immunity recipients from joint and several liability, as evidence provided by immunity recipients is of considerable aid to the determination of a competition law infringement. It is possible that because of the exception rules concerning immunity recipients, a minor part of competition-based harms will not be recovered, but it is quite possible that without the fact-finding activity of immunity recipients, injured parties would not receive any compensation at all, as they could not prove the unlawfulness of the conduct. Only the national report from Lithuania ${ }^{12}$ expressed doubts about both exceptions, that is, not only in connection to SMEs but immunity recipients as well (Mikelènas and Zaščiurinskaite, 2017, p. 193). At this point, the question arises whether there

12 It might be debatable whether those exemptions are necessary and can be justified based on the principles of justice, reasonableness and good faith. (National report of Lithuania). 
is a need for exceptions, on the one hand, and, on the other hand, whether the existence of exceptions from joint and several liability is in compliance with the principle of justice, reasonableness and good faith.

The SMEs' exemption from joint and several liability gives food for thought based on the national report from Hungary. In this case, the Directive favours a given group of entities (SMEs) who do not improve the position of the injured parties (Miskolczi Bodnár, 2017, p. 129 and 140).

The SMEs exemption from joint and several liability is based only on reasons other than the right to compensation (such as preservation of employment, social aspects). In practice, it is not expected that the position of the injured parties will substantially deteriorate due to the SMEs exemption, as only those SMEs are exempted from joint and several liability pursuant to the Directive, from who injured parties cannot expect considerable damages anyway. However, it is dogmatically difficult to explain why the Directive exempts some infringers to the detriment of injured parties, while it was adopted in order to facilitate full compensation. The Polish national report (Piszcz and Wolski, 2017 , p. 220) draws attention to the realisation that the financial position of a SME is difficult to assess; that is, whether its financial standing is consistent with point $2 \mathrm{~b}$ of Article 11 of the Damages Directive ('the application of the normal rules of joint and several liability would irretrievably jeopardise its economic viability and cause its assets to lose all their value'). Therefore, it is doubtful whether the SMEs exemption from joint and several liability is feasible in light of the provisions of the Damages Directive.

\section{Position of immunity recipients in national laws}

When it comes to the exceptions to joint and several liability, national reports generally state that domestic rules have been harmonized accordingly. We are forced to note that the 11 national reports do not discuss the rules on joint and several liability with the same level of detail (some national reports contain only one page on the problem of the joint and several liability and the exceptions to joint and several liability). As a consequence, it may not be excluded with certainty that there are discrepancies between the Directive and the provisions of national laws concerning immunity recipients.

During the examination, we separate the position of immunity recipients and the injured parties, on the one hand, and the position of immunity recipients and other co-infringers, on the other hand. 


\section{Relationship of the immunity recipient and the injured parties}

CEE countries implemented (plan to implement) the rules of the Damages Directive regarding the varying level of liability of immunity recipients, which differs depending on who the injured party is. Immunity recipients are jointly and severally liable with other co-infringers for the harm suffered by their own direct and indirect purchasers and providers. Immunity recipients are in a better position regarding harm suffered by injured entities that are not their own direct and indirect purchasers and providers, because these harms shall only be compensated by an immunity recipient in the event that such injured parties have not received sufficient compensation from other co-infringers.

After the adoption of the Damages Directive, the majority of CCE countries transposed these provisions as new rules. However, Hungary and Slovakia had introduced an exception regarding immunity recipients into their national laws earlier in light of the White Paper (Miskolczi Bodnár, 2017, p. 129 and Blažo, 2017 , p. 253). These rules were more beneficial to the immunity recipients than the relevant norms of the Damages Directive. These rules were applicable for a relatively short period of time only in these two countries. Norms on legal position of the immunity recipients were adjusted to the norms of the Damages Directive in December 2016.

Only the Romanian national report informs us that immunity recipients shall not bear joint and several liability, but only joint liability towards their own direct and indirect purchasers (Mircea, 2017, p. 240). The Romanian national report does not mention injured 'providers'; in the Damages Directive, the rules on liability towards providers are the same as on harm caused to own direct and indirect purchasers of the immunity recipient.

\section{Relationship of the immunity recipient and other co-infringers}

In light of those national reports that also considered this question, ${ }^{13}$ the legislation of CEE countries transposed the rule of the Damages Directive regarding claims for the payment of a contribution to damages already covered submitted by the co-infringer that had actually compensated the harm.

We highlight three of the issues related to claims for the payment of a contribution towards damages already covered.

13 Croatia, Czech Republic, Estonia 


\subsection{Starting date of the payment obligation of the immunity recipient}

The national report of Croatia points out that the starting date of the payment obligation of the immunity recipients is not clarified in the Damages Directive. 'It is very unclear what is the determining moment when the claim against other co-infringers shall be deemed unsuccessful, consequentially triggering the right of such victims to request compensation from the immunity recipient.' (Butorac Malnar, 2017, p. 65).

According to the Croatian national report, the date when the decision is taken on the irrecoverable nature of compensation from other co-infringers may be considered as the date when the position of the immunity recipient changes. Nevertheless, the date when pubic enforcement proceedings are to be considered finally unsuccessful is uncertain. This uncertainty jeopardizes the full compensation of injured parties (Butorac Malnar, 2017, p. 65).

Issues connected to the claim for contribution.

\subsection{Factors determining the internal share of the responsibility among co-infringers}

Some of the national rapporteurs expressed their disappointment about the shortcomings of the legislation.

The national report from Latvia ${ }^{14}$ wished for more precise guidance concerning the share of responsibility among the persons liable jointly and severally (Jerneva and Druviete, 2017, p. 162). The Latvian national report noted that it would be necessary to settle this issue before concrete legal disputes ensue, facilitating the work of the parties and the court.

The Croatian draft legislation indicates some factors to be taken into account during the determination of internal responsibility allocations (like the circumstances of the case, the market share, the turnover and the role in the competition infringements of the infringers, regardless of whose purchaser or provider the injured party is). This list partially follows the rules detailed in recital 37 of the Damages Directive (Butorac Malnar, 2017, p. 65).

In the other group of CEE countries, national reports did not raise any complaints about shortcomings regarding rules on joint and several liability, presumably because their civil law norms regulate this question and the respective Member States found these general rules appropriate also for harm caused jointly by multiple competition law infringements.

14 It remains to be seen how the identification of the relative share of responsibility will take place in practice. The Amendments are silent on this matter, while it would be practical to try to resolve these issues beforehand and include, for example, a rebuttable presumption of equal share of liability, or give general guidelines which would assist the parties to the dispute as well as the judge. 
The Estonian act on contract law prescribes the taking into account of all essential circumstances for each person (including, but not limited to, the gravity of non-performance, the unlawful nature of the conduct and the degree of arising risk) during the determination of the share of co-infringers. The Estonian national report does not refer to the fact that the authors of the report considered the supplementing necessary in case of harms jointly caused by competition law infringements (Pärn-Lee, 2017, p. 113).

The Hungarian national report cites the rules set out in the Civil Code ${ }^{15}$ as well, and assumes that those circumstances govern the relationship of co-infringers in the case of harm caused by competition infringement as well (Miskolczi Bodnár, 2017, p. 129).

\subsection{Maximum degree of liability of the immunity recipient}

The Croatian and the Latvian national reports (Butorac Malnar, 2017, p. 65 and Jerneva and Druviete, 2017, p. 162) point out that based on the Damages Directive, the maximum degree of the liability of an immunity recipient is different, depending on whether the injured party is

(1) a person, who is not 'own direct or indirect purchaser or provider of the immunity recipient', but the direct or indirect purchaser or provider of any of the other co-infringers, as well as,

(2) a person, who is not in a relationship as 'own direct or indirect purchaser or provider' with either the immunity recipient or any of the co-infringers (so-called umbrella customer or competitor).

The maximum degree of liability set out in Article 11(5) of the Damages Directive governs the first case; in the second case however, the liability of the immunity recipient adjusts to the share of liability without a special maximum limit.

\section{Exemption of SMEs from joint and several liability in national laws}

\section{Scope ratione personae of the special liability rule}

The national report of Slovenia draws attention to the realisation that the Damages Directive contains only provisions concerning small and mediumsized enterprises, even though it refers to Commission Recommendation

15 Hungarian Civil code uses a three steps system. The first step is the degree of the tortfeasors culpability. The second step - if the culpability cannot be determined - in proportion to tortfeasors respective involvements. If the degree of involvement cannot be verified, tortfeasors shall cover the damages equally. 
2003/361/EC the very title of which speaks of micro, small and medium-sized enterprises. Therefore, rules of the Directive that must be implemented by the member States only with regard to small and medium-sized enterprises shall be applied in Slovenian law also to micro enterprises, in connection with the compensation of harms caused by infringements of competition law (Vlahek and Podobnik, 2017, p. 279).

The national report of Slovakia, similarly to Slovenia, mentions that Commission Recommendation 2003/361/EC is also applicable to micro enterprises as well as mentions that Commission Regulation (EU) No. 651/2014 of 17 June 2014 is also applicable to micro enterprises (Blažo, 2017, p. 253).

The national report of Slovakia draws the attention to that although the Damages Directive refers to Commission Recommendation 2003/361/ EC in connection with SMEs, SMEs are, in fact, defined in EU law in Commission Regulation (EU) No. 651/2014 (Blažo, 2017, p. 253). However, in light of the Directive, a significant part of CEE countries refers to Commission Recommendation 2003/361/EC in connection with the definition of SMEs.

Pursuant to the Czech parliamentary proposition, the definition of SMEs may not only cover undertakings but also associations of persons.

To the elements of the definition of SMEs, the Hungarian legislator added that the infringer must fulfil the requirements of being a 'SME' during the whole duration of the unlawful behaviour (Miskolczi Bodnár, 2017, p. 129 and 140).

\section{Whether SMEs are exceptions to joint and several liability?}

In this point we examine whether the $11 \mathrm{CEE}$ exempt SMEs from joint and several liability in cases provided for in the Damages Directive.

The vast majority of CEE countries follow the Damages Directive in connection with

(1) the exception to the general rule, namely SMEs are exempted from joint and several liability (Article 11(2) of the Damages Directive),

(2) the conditions (Article 11(2) a) and b) of the Damages Directive), and

(3) exceptions, namely SMEs are not exempted from joint and several liability (Article 11(3) a) and b) of the Damages Directive).

The legislation of some CEE countries considered, however, the protection of the injured parties more important than transposing the Directive verbatim.

Act 350 of 2016 passed in December 2016 in Slovakia obliges SMEs (just like immunity recipients) to compensate harm suffered by persons other than their direct and indirect purchasers if they were not compensated by other 
co-infringers participating in the same competition infringement. By this solution, the Slovakian legislator seeks to balance the solution beneficial for SMEs and the principle of full compensation (Blažo, 2017, p. 253).

The Estonian draft follows, in general, the Directive literally. However, it differs from the Directive in connection with the exception to joint and several liability of SMEs. The exemption from joint and several liability shall not be applied to SMEs if the harm caused to their direct or indirect purchasers is not compensated by other co-infringers (Pärn-Lee, 2017, p. 113).

The national report from Croatia also states that the national legislator considered the difference in the detailed rules concerning the two exceptions to joint and several liability as unjustified. According to the Croatian standpoint, there is an unintended difference in favour of SMEs in the Damages Directive: while immunity recipients bear a certain obligation to reimburse (also if the degree of that duty is limited), SMEs do not have such obligation (Butorac Malnar, 2017, p. 65).

Czech legislation makes the SMEs liable for harm, if such harm has not been compensated by other co-infringers. According to the national report, this rule was inspired by the norm on immunity recipients (Petr, 2017, p. 91).

The Slovenian legislator also decided to extend the liability conditions applicable to immunity recipients also to SMEs - if the harm cannot be compensated by anybody else, these two groups shall pay the compensation as a last resort (Vlahek and Podobnik, 2017, p. 279).

Hungarian regulation considers only the situation if the damages may not, or not fully, be compensated by other - non-SMEs - undertakings liable for the same infringement. Thus, the Hungarian legislator also takes into consideration if there are further SMEs among the co-infringers (Miskolczi Bodnár, 2017, p. 129 and 140).

\section{Circumstances underlying the exemption to joint and several liability of SMEs}

The Polish national report points out that courts must face difficulties when they shall determine whether the application of the general rules regarding joint and several liability would cause a given SME to lose its economic viability and impairment of all its assets (Piszcz and Wolski, 2017, p. 220). 


\section{To what kind of harm is the principal responsibility of SMEs limited?}

The Damages Directive differentiates among harms in connection with the liability of SMEs, and places harms caused by a SME to its own direct and indirect purchasers in the first category. This list concerns a narrower meaning of harms than the list applied in connection with the liability of immunity recipients. In case of SMEs, the Damages Directive does not mention harms caused to the direct and indirect providers of SMEs, just to its direct and indirect purchasers.

The majority of the CEE countries transposed literally the list found in the Damages Directive, thus SMEs are exempted from the obligation of compensating harm caused to their own direct and indirect providers.

However, some CEE countries have completed the list of relevant harms by the addition of harm caused to direct and indirect providers of SMEs. According to Hungarian law ${ }^{16}$ (Miskolczi Bodnár, 2017, p. 140), the liability of SMEs covers also harms suffered by their direct and indirect providers (rather than only harms suffered by their direct and indirect purchasers). According to Czech law, SMEs are liable for harms caused to their providers as well (Butorac Malnar, 2017, p. 65). The Czech national rapporteur expressively describes the aforementioned divergence from the Damages Directive as reasonable, assuming that providers have simply been omitted in error in point 2 of Article 11 of the Directive. Also in connection with the Polish draft, Anna Piszcz informs us in the synthesis of the national reports that according to Polish law the liability of SMEs covers also harms suffered by their direct and indirect providers (Piszcz, 2017a, p. 302).

\section{Links of the regulation}

Joint and several liability as a general rule and its two exceptions are connected to the following questions.

\section{Liability of a co-infringer reaching a settlement through consensual dispute resolution}

In this study, we have not dealt with the special status of a competition law infringer who reaches a settlement with an injured party through consensual dispute resolution. In general, following a consensual settlement, the claim

16 Art. 88/H(2) of the Hungarian Competition Act. 
of the settling injured party is reduced by the settling co-infringer's share of the harm that the infringement of competition law inflicted upon that injured party. ${ }^{17}$ In exceptional cases, it shall compensate these harms as well, if this part of the harm of the injured party will not be covered by other co-infringers. However, this liability of a compensatory nature may be excluded in the settlement itself. ${ }^{18}$ Co-infringers may submit a claim for partial reimbursement in their internal relations. In such cases, national courts shall take sufficiently into account compensation paid as a result of a settlement reached earlier by way of consensual dispute resolution. ${ }^{19}$

Consensual settlements lead to faster compensation of a part of the harms and are not as costly. It depends on the injured party which part of its claim for damages it will waive in that regard, and makes future recovery riskier.

\section{Liability of parent companies}

If neither of the other co-infringers nor the defendant co-infringer gave compensation for the harm or part thereof, but the person obliged to compensate it has a parent company, then liability of its parent company may arise, as in competition law (Joshua, Bottemann and Atlee, 2011, p. 4). This may solve the problem, especially in case of insolvency of SMEs. The fact that the parent company withdrew its share capital from the subsidiary, or gave the profit stemming from the SME to another member of the corporate group, gives rise to the liability of the parent company towards the creditors i.e. the injured parties. This leads us into another legal field - corporate law - which is characterised by far greater diversion of national norms than tort law. For example, in Bulgaria there is no possibility of the application of the institution of 'piercing the corporate veil' (Petrov, 2017, p. 37).

\section{Proposal}

The normal course of an assessment related to the implementation of a directive is whether the Member States have performed their legal harmonization duties on time, whether the implementation of the rules of the directive was complete, and to what an extent national norms deviates from it. This study on the material issues of the implementation of the general

\footnotetext{
17 Damages Directive, Art. 19(2).

18 Ibidem, Art. 19(3).

19 Ibidem, Art. 19(4).
} 
rule of joint and several liability, as well as exceptions granted in this regard to immunity recipients and SMEs, may be concluded with a generally positive assessment following the traditional scenario. It is a fact that the norms of the Directive were implemented and that there is no deviation that might jeopardize either the enforcement of claims for damages or the integrity of the internal market.

The question arises how much the Damages Directive did facilitate the duties of transposition. We must note that the length of the harmonization process is largely attributable to the difficulties of the topic and its complexity. Many partly contradictory interests had to be taken into account, the aspects of public and private law had to be placed on a common platform, and the application of many legal instruments (compensation in civil law, protection of confidentiality, civil procedure) had to be harmonized. The Damages Directive largely explained the reasoning behind its chosen solutions, and clearly determined the norms to be implemented. However, there is an exception the SMEs exemption - where it would not be appropriate to wait the whole 10 years for a routine review of the workings of the directive.

The doctrine related to the SMEs exemption draws attention to the realisation that it is unfortunate when a solution, that arose in a relatively late stage of the legislative process of a given directive, ultimately becomes part of that directive. Neither the Green Paper of 2005 nor the White Paper of 2008 mentioned SMEs with respect to exceptions to joint and several liability. This shows that the actual period of time spent on developing the final solution on this topic was much shorter.

The implementation of these rules is required by the Damages Directive only with regard to small and medium-sized enterprises. It would, however, seem practical, for example, to declare those rules applicable also to micro enterprises, in relation with the compensation of harms caused by infringements of competition law.

It would have been appropriate in any case to spell out the reasons for the introduction of such new legal institution in the Preamble of the Directive. Unfortunately, none of the 56 recitals of the Damages Directive deal with the special status granted to SMEs, thus a national legislator is forced to speculate during the implementation process.

It would have been duly justified to provide such an explanation, especially when two exceptions are established but their rules differ even from each other. It was visible that some CEE countries considered this difference unjustified, and thus uniformly ensured an opportunity for other co-infringers who actually compensated the harm of the injured party to submit a claim for reimbursement against the immunity recipient and SMEs. At the same time, other CEE countries considered that their powers do not cover it. 
It would be worth reviewing the implementation of the exceptions to joint and several liability after a year, in conjunction with the issue of alternative dispute resolution. Though the national reports on laws and draft laws (which have not been adopted yet and have not entered into force) mainly highlighted substantive similarities, there is a significant chance that more discrepancies come to light in the future among the provisions concerning the final national legal texts and the Damages Directive. It would be appropriate to make a comparison again, after the European Commission explains in detail the discrepancies and the difficulties of interpretation that will emerge as to how, and who was meant to be exempted from joint and several liability. In our opinion, the currently visible discrepancies are partly due to Member States not having received sufficient information from the European Commission about the goals underlying the norms of the Directive.

\section{Literature}

Blažo, O. (2017). Slovakia. In: A. Piszcz (ed.), Implementation of the EU Damages Directive in Central and Eastern European Countries. Warsaw: University of Warsaw, Faculty of Management Press.

Butorac Malnar, V. (2017). Croatia. In: A. Piszcz (ed.), Implementation of the EU Damages Directive in Central and Eastern European Countries. Warsaw: University of Warsaw, Faculty of Management Press.

Jerneva, J. and Druviete, I (2017). Latvia. In: A. Piszcz (ed.), Implementation of the EU Damages Directive in Central and Eastern European Countries. Warsaw: University of Warsaw Faculty of Management Press.

Joshua, J., Bottemann, Y. and Atlee L. (2011). 'You Can't Beat the Percentage' - The Parental Liability Presumption in EU Cartel Enforcement. The European Antitrust Review 2012, p. 3-9.

Mikelénas, V. and Zaščiurinskaité, R. (2017). Lithuania. In: A. Piszcz (ed.), Implementation of the EU Damages Directive in Central and Eastern European Countries. Warsaw: University of Warsaw Faculty of Management Press.

Mircea, V. (2017). Romania. In: A. Piszcz (ed.), Implementation of the EU Damages Directive in Central and Eastern European Countries. Warsaw: University of Warsaw Faculty of Management Press.

Miskolczi Bodnár, P. (2017). Hungary. In: A. Piszcz (ed.), Implementation of the EU Damages Directive in Central and Eastern European Countries. Warsaw: University of Warsaw Faculty of Management Press.

Pärn-Lee, E. (2017). Estonia. In: A. Piszcz (ed.), Implementation of the EU Damages Directive in Central and Eastern European Countries. Warsaw: University of Warsaw Faculty of Management Press. 
Petr, M. (2017). Czech Republic. In: A. Piszcz (ed.), Implementation of the EU Damages Directive in Central and Eastern European Countries. Warsaw: University of Warsaw Faculty of Management Press.

Petrov, A. (2017). Bulgaria. In: A. Piszcz (ed.), Implementation of the EU Damages Directive in Central and Eastern European Countries. Warsaw: University of Warsaw Faculty of Management Press.

Peyer, S. (2016). Compensation and the Damages Directive. European Competition Journal, 12(1), p. 87-112.

Piszcz, A. and Wolski, A. (2017). Poland. In: A. Piszcz (ed.), Implementation of the EU Damages Directive in Central and Eastern European Countries. Warsaw: University of Warsaw Faculty of Management Press.

Piszcz, A. (2017). Introduction to the issues of the implementation of the EU Damages Directive in CEE countries. In: A. Piszcz (ed.), Implementation of the EU Damages Directive in Central and Eastern European Countries. Warsaw: University of Warsaw Faculty of Management Press.

Piszcz, A. (2017a). Quo vadis CEE? Summary in Implementation of the EU Damages Directive. In: A. Piszcz (ed.), Implementation of the EU Damages Directive in Central and Eastern European Countries. Warsaw: University of Warsaw Faculty of Management Press.

Vlahek, A. and Podobnik, K. (2017). Slovenia. In: A. Piszcz (ed.), Implementation of the EU Damages Directive in Central and Eastern European Countries. Warsaw: University of Warsaw Faculty of Management Press. 